WARSZTATY Z GEOGRAFII TURYZMU

ISBN 978-83-7525-925-4 s. 199-215

http://dx.doi.org/10.18778/7525-925-4.13

Mateusz ROGOWSKI

Wyższa Szkoła Handlu i Usług

Michał KUC

Uniwersytet Wrocławski

\title{
MOŻLIWOŚCI ROZWOJU TURYSTYKI PIWNEJ W OPARCIU O BROWARY REGIONALNE WIELKOPOLSKI, DOLNEGO ŚLĄSKA I ZIEMI LUBUSKIEJ
}

\section{Wstęp}

Wielkopolska, Dolny Śląsk i Ziemia Lubuska, położone w zachodniej części Polski, przez wieki były obszarem wzajemnego oddziaływania wpływów polskich, niemieckich i czeskich. Począwszy od powstania Marchii Brandenburskiej w XII w., przez istnienie Księstwa i Królestwa Pruskiego oraz Cesarstwa Niemieckiego, wspomniany teren, okresowo - w całości lub we fragmentach - był pod panowaniem Niemiec. Podobnie było w przypadku historii ziem dolnośląskich, które w całości lub częściowo były pod władaniem Królestwa Czeskiego czy Monarchii Austro-Węgierskiej. Powodowało to, że zwyczaje naszych sąsiadów, obejmujące także piwowarstwo, bardzo szybko zakorzeniały się wśród rdzennej ludności tych obszarów. Na tle wymienionych uwarunkowań historyczno-kulturalnych pośród ludności zamieszkującej analizowany obszar, bardzo trwale zakorzeniła się działalność piwowarska regionalnych browarów. 
Celem niniejszej pracy jest charakterystyka i ocena siedmiu obecnie działających browarów regionalnych w województwach wielkopolskim, dolnośląskim i lubuskim pod kątem możliwości rozwoju turystyki piwnej. Do zadań szczegółowych należy charakterystyka tych obiektów w oparciu o sześć kryteriów stworzonych na potrzeby analizy regionalnych browarów w Polsce (ROGOWSKI, KUC, KUC 2012), które zostały scharakteryzowane w dalszej części pracy.

\section{Zarys historii piwowarstwa na omawianym obszarze}

Historia piwowarstwa na obecnym obszarze Polski sięga okresu średniowiecza, kiedy rozpoczęto nadawać miastom królewskie przywileje warzenia piwa. Już w tym czasie przepisy warzelnicze były rygorystyczne, stawiały na pierwszym miejscu jakość piwa, a ich nieprzestrzeganie groziło utratą tego prawa.

Początki browarnictwa na omawianym obszarze sięgają XIII w., wiążąc się według A. GALAS i A. GALASA (2004) z wielką akcją kolonizacyjną która przeobraziła gospodarcze i społeczne oblicze Dolnego Śląska, a z czasem całej tzw. Polski piastowskiej. Kolejne wieki sprzyjały rozwojowi browarnictwa, szczególnie za sprawą ciągle ulepszanej technologii produktu oraz jakości trunku. Od XVIII w., gdy ziemie te zostały objęte zaborem pruskim, nastąpiły najintensywniejsze przeobrażenia istniejących browarów.

Najstarszym spośród obecnie działających browarów regionalnych jest Lwówek Śląski. Jego powstanie w 1209 r. wiązało się z budową piastowskiego zamku przez księcia Bolesława Kędzierzawego. Po zakończeniu inwestycji w zamku osadzono kasztelana, który nakazał utworzyć browar ze słodownią. Warzone w nim piwo spożywane było głównie na zamku przez ród książęcy, a z czasem przez mieszczan. W kolejnych wiekach wskutek bardzo silnej konkurencji innych browarów dolnośląskich browar Lwówek stracił na znaczeniu. W 1845 r. Bractwo Piwowarskie, po nieudanych próbach uratowania upadającego browaru, wystawiło go na sprzedaż. W $1871 \mathrm{r}$. browar został zakupiony przez Juliusza Hohberga z Kowar, który natychmiast przystąpił do modernizacji przedsiębiorstwa. Jego głównym celem stało się stworzenie doskonałego piwa i wyparcie popularnego piwa z Jawora. W kolejnych latach wzniesiono słodownię i zainstalowano urządzenie paro- 
we do produkcji sztucznego lodu, co pomogło w wyprodukowaniu dwóch kolejnych gatunków piwa: eksportowego i koźlaka (http://zabytki.powiat lwowecki.info/index.php/ciekawe-historie/26-zabytki/niezwykle-historie/50historia-lwoweckiego-piwowarstwa).

Na Ziemi Lubuskiej w XIV w. niewielka osada Vitz (dzisiejsza Witnica), położona w dolinie dolnej Warty, stała się własnością zakonu cysterskiego. Na mocy posiadanego przywileju bracia zakonni rozpoczęli warzenie piwa klasztornego. Po kasacie zakonu wieś Witnica będąca lennem niemieckiego kolonisty, nadal miała ten przywilej. Jako datę założenia obecnego browaru Witnica uznaje się rok 1848, kiedy Ernest Ferdinand Handke wydzierżawił istniejący już browar i gospodę od rodziny Feuerhermów, a następnie w 1856 r. - przejął je na własność. Po rozbudowie przedsiębiorstwa w drugiej połowie XIX w. stało się ono jednym z najnowocześniejszych małych browarów w północnej części państwa pruskiego. Funkcjonując pod nazwą Stern Brau udoskonaliło proces fermentacji i na dobrym jakościowo chmielu zaczęto warzyć piwo - znane jako „bawarskie” (http://sklep.browar-witnica. $\mathrm{pl} /$ strony/historia).

W okresie XVI i XVII w. na terenie Wielkopolski działało kilka browarów, wśród których był m.in. najstarszy, obecnie nieczynny, w Grodzisku Wielkopolskim. W 1626 r. dokonano urzędowego wpisu o ugotowaniu dziewiczych porcji piwa w Miłosławiu, który bardzo szybko stał się nowym i prężnym ośrodkiem piwowarskim, o czym najlepiej świadczy tzw. czopowe, czyli odpowiednik współczesnego podatku akcyzowego. Płaciło je 36 mielcarzy (jak wówczas nazywano piwowarów). Pod koniec XVIII w. piwo miłosławskie cieszyło się już zasłużoną sławą gdyż wysyłano je do Gdańska, skąd okrętami wywożono je za granicę. Od 1889 r. w Miłosławiu nastała nowa era piwowarstwa, kiedy staraniem okolicznych mieszczan wybudowano nowoczesny browar parowy Fortuna (http://www.browarfortuna.pl/ historia_browaru/). Browar w Czarnkowie został wzniesiony na miejscu dawnego zamku Nałęczów-Czarnkowskich, nosząc nazwę Brauerei Streich. W roku 1893 zakład nabył Heinrich Koeppe, który dokonał jego gruntownej przebudowy zmieniając nazwę na Schlossbraurei, czyli browar Zamkowy (http://browarczarnkow.pl/o-browarze/).

Po II wojnie światowej wszystkie browary ziem zachodnich zostały znacjonalizowane, co doprowadziło do ich stopniowego upadku. Dopiero lata 90. XX w. ożywiły sytuację, a browary przeszły w ręce prywatnych inwestorów lub wróciły do spadkobierców. Okres ten wiązał się z intensywnymi 
pracami modernizacyjnymi i przystosowaniem się do reguł wolnego rynku. Ponadto w tym czasie powstały także trzy nowe regionalne browary: Bartek we wsi Cieśle pod Pleszewem, Edi w Nowej Wsi pod Wschową i Zodiak we wsi Bierzwienna Długa - Kolonia pod Kłodawą. Do dziś na terenie Wielkopolski, Dolnego Śląska i Ziemi Lubuskiej istnieje siedem browarów produkujących 80 marek piwa.

\section{Ogólna charakterystyka browarów i gatunków piw}

Browary objęte analizą można podzielić na dwie grupy, uwzględniając ich walory turystyczne:

- stare browary, współtworzące historię polskiego piwowarstwa (Lwówek Śląski, Witnica, Czarnków i Fortuna), mają walory krajoznawcze o znaczeniu historycznym, a produkowane piwa nawiązują do starych, tradycyjnych marek - motywem przyjazdów turystów jest chęć poznania historii browarnictwa $\mathrm{w}$ regionie i smakowanie dobrej jakości piwa produkowanego metodami „nieprzemysłowymi”, stworzonymi i utrwalonymi na przestrzeni kilkuset lat;

- nowe browary (Bartek, Edi i Zodiak) oferujące własne, często unikatowe marki piwa produkowane na rynek regionalny - motywem przyjazdu turystów jest głównie smakowanie piwa.

Dynamicznie rozwijająca się sytuacja na polskim rynku browarów regionalnych zaowocowała zakupieniem w 2012 r. najstarszego browaru Wielkopolskiego w Grodzisku Wielkopolskim przez właścicieli browaru Fortuna oraz XIX-wiecznego Starego Browaru w Bojanowie przez właściciela browaru Lwówek Śląski. Tym samym planowane jest wznowienie produkcji w 2013 r., co spowoduje zwiększenie liczby działających browarów regionalnych (http://pgo24.pl/2012/08/fortuna-nabywca-browaru-w-grodzisku-wiel kopolskim/).

Najczęściej stosuje się podział piw ze względu na rodzaj odbywającej się ich fermentacji, tj.:

- dolnej (częściej stosowanej), przebiegającej się $\mathrm{w}$ temperaturze $10^{\circ} \mathrm{C}$, gdy drożdże opadają na dno fermentatora;

- górnej (starszej i szlachetniejszej), odbywającej się w temperaturze od 16 do $24^{\circ} \mathrm{C}$, gdy drożdże gromadzą się na powierzchni fermentatora, 
a piwo zawiera większą ilość wyższych alkoholi oraz estrów decydujących o bogatszym bukiecie smaku.

Analizowane browary produkują głównie piwa dolnej fermentacji:

a) lager - jasne, o długim czasie przechowywania (niem. lagern oznacza leżakowanie - JACKSON 2007), jego odmiany - aromatyzowane miodowe i owocowe oraz marcowe warzone wiosna, a serwowane jesienią, (głównie w czasie festiwalu "Oktoberfest"),

b) pils (pilzner) - o większej goryczy i zawierający mniej alkoholu i ekstraktu,

c) koźlak - ciemne, dłużej fermentujące i leżakujące, o wyższym poziomie alkoholu i ekstraktu, oraz

d) porter bałtycki - ciemne i bardzo mocne (http://www.ratebeer.com, http://www.smaki-piwa.pl).

Cztery browary - Fortuna, Lwówek Śląski, Witnica i Bartek - produkują piwa górnej fermentacji: pszeniczne (niemiecki wiessbier) oraz klasztorne (belgijskie), ale dubbel i tripel (dwu- lub trzykrotnie fermentujące).

\section{Turystyka piwna}

Wielkopolska, Dolny Śląsk i Ziemia Lubuska mając długie i bogate tradycje piwowarstwa stanowią regiony o dużych predyspozycjach do rozwoju turystyki piwnej w oparciu o regionalne browary. Przynajmniej połowa z nich jest w stanie przedstawić ciekawą ofertę, stanowiącą odpowiedź na coraz większe zainteresowanie turystów tego typu atrakcjami. Swoistym uzupełnieniem mogą być festiwale kulinarne oferujące duży wybór potraw i napojów, a także imprezy regionalne. Piwo wraz z całą otoczką produkcyjną i promocyjną nieodzownie wiąże się z turystyką kulinarną (ang. food tourism), w przypadku której turystyka piwna (ang. beer tourism) odgrywa coraz istotniejszą rolę. Polska, mając korzystne warunki do uprawy zbóż i bogate tradycje kulinarne, jest krajem o dużych predyspozycjach rozwoju tej formy turystyki. Wpływa na to również postępująca zmiana preferencji w spożyciu alkoholu przez Polaków na korzyść trunków niskoprocentowych oraz głęboko zakorzenionej tradycji spożycia piwa podczas spotkań towarzyskich (Społeczny kontekst picia piwa... 2003). Dzięki temu krystalizuje się coraz wyraźniej grupa konsumentów o wyższych wymaganiach dotyczących jakości 
i smaku piwa, a także zainteresowana sposobami jego produkcji (http:// urlopw.pl/turystyka-piwna-nowy-trend-turystyczny/). Osoby te stanowią specyficzny segment turystów związany z produktem turystyki piwnej, a ich motywami jest nie tylko pragnienie skosztowania dobrej jakości regional nego piwa, ale także poznanie procesu jego produkcji, odwiedzenie muzeum browarnictwa oraz uczestnictwo $\mathrm{w}$ festiwalach tradycji piwowarskich, kulinarnych i imprezach regionalnych oferujących ten trunek. $Z$ tego względu wyróżniono trzy formy turystyki piwnej w zależności od motywów (ROGOWSKI, KUC, KUC 2012):

- podróże w celu smakowania dobrej jakości piwa, w przypadku których motywem przewodnim jest stworzenie własnego rankingu poszczególnych gatunków i marek;

- podróże w celu poznania historii browarnictwa, gdzie istotne jest poznanie tradycji i technologia produkcji oraz zastosowanie unikatowych składników i procedur podczas wytwarzania;

- podróże w celu uczestnictwa w festiwalach kulinarnych i imprezach regionalnych, których głównym motywem jest skosztowanie piwa jako składnika dziedzictwa kulinarnego regionu.

Problematyka piwna nie była zbyt często podejmowana $\mathrm{w}$ literaturze naukowej (np. KOSMACZEWSKA 2008, OTTO 2012, ROGOWSKI, KUC, KUC 2012). $\mathrm{O}$ wiele bogatsza jest literatura przewodnikowa, do której można zaliczyć m.in. przewodniki po najlepszych polskich pubach piwnych (BIKONT, MAKŁOWICZ 2003), polskich browarach (FAŁAT i in., 2003, STROJNY 2009) oraz po szlakach piwnych Europy Środkowej (STROJNY 2003) i Czechach z uwzględnieniem atrakcji piwnych (KRAUSOVA-ŻUR 2010).

\section{Potencjał turystyczny regionalnych browarów Wielkopolski, Dolnego Śląska i Ziemi Lubuskiej}

Nawiązując do analizy potencjału turystycznego browarów regionalnych w Polsce uszczegółowiono charakterystykę siedmiu obiektów zlokalizowanych $\mathrm{w}$ regionach o najdłuższej tradycji piwowarstwa. Próba ta została wykonana w oparciu o następujące kryteria (ROGOWSKI, KUC, KUC 2012):

1) historyczności, określające związek browaru z lokalną historią i rozwojem społeczno-gospodarczym regionu, co tym samym podkreśla 
istotność obiektu w historii miasta/wsi i regionu; produkcja piwa jest najczęściej związana z długą tradycją jego wytwarzania, mając większe możliwości rozwoju działalności muzealnej i jego atrakcyjności turystycznej;

2) dziedzictwa materialnego browaru, uwzględniającego przystosowanie obiektów browaru do potrzeb turystyki, w postaci muzeum browarnictwa z różnorodnym wyposażeniem oraz możliwość zwiedzania wnętrz i degustacji piwa, a także zabytkowy charakter budynku;

3) dziedzictwa niematerialnego browaru, związanego $z$ jego uczestnictwem $\mathrm{w}$ festiwalach tradycji kulinarnej i imprezach regionalnych;

4) różnorodności gatunków - wyróżniając piwa zgodnie z podziałem na produkty dolnej i górnej fermentacji, stopień utrwalenia oraz smak (im większa różnorodność gatunków, tym większe zainteresowanie poszczególnymi piwami przez potencjalnych klientów i większe zróżnicowanie $\mathrm{w}$ smaku, a tym samym bogatsze doznania $\mathrm{w}$ odbiorze produktów jednego producenta);

5) liczby marek produkowanych piw, charakteryzujących ilościową ofertę przeznaczoną na rynek konsumencki;

6) dostępności produktu na rynku - związane z zasięgiem piwa na ryn$\mathrm{ku}$; jeśli trunek jest dostępny wyłącznie na rynku regionalnym, to ze względu na swoją unikatowość bywa większą atrakcją dla turystów.

Informacje do analizy pozyskano wyłącznie z oficjalnych stron internetowych browarów, uznając je za najwiarygodniejsze źródło danych.

Ad 1. Historyczność, czyli związek browaru z lokalną historią i rozwojem społeczno-gospodarczym regionu, który jest istotny dla walorów krajoznawczych obiektu, w przypadku których uwzględnia się, zweryfikowaną w oparciu o źródła historyczne, datację produkcji piwa w danym browarze, aby móc szczycić się nią w materiałach promocyjnych i na oficjalnej stronie internetowej (rys. 1). Najstarszym, nie tylko spośród analizowanych obiektów, ale na obecnych ziemiach polskich, jest Browar Lwówek Śląski (1209 r.) - ciągłość tradycji piwowarskiej sięgająca średniowiecznych czasów Piastów śląskich. W przypadku kolejnych, pomimo informacji o wcześniejszym istnieniu browarów w Witnicy (XIV w.), Miłosławiu (XVII w.) oraz Czarnkowie (XVIII w.), za właściwe uznawane przez właścicieli przyjmuje się daty przejęcia i modernizacji istniejących już obiektów. Są to późniejsze daty: $1848 \mathrm{r}$. dla Witnicy, 1889 r. dla Fortuny i 1893 r. dla Czarnkowa. Pozostałe browary 
powstały w okresie rozwoju wolnego rynku w latach 90. XX w., nie mając istotnego związku $\mathrm{z}$ historią i dziedzictwem regionu.

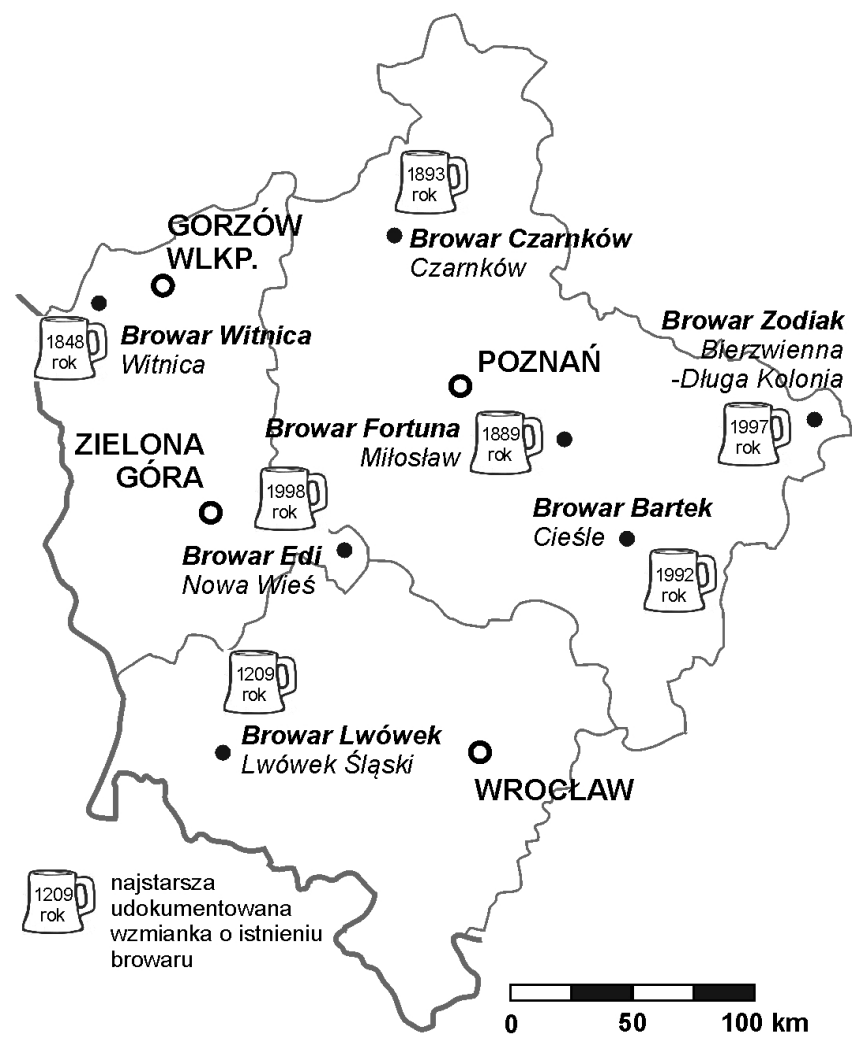

Rys. 1. Rok powstania browarów regionalnych Wielkopolski,

Dolnego Śląska i Ziemi Lubuskiej

Źródło: opracowanie własne na podstawie danych

$\mathrm{z}$ oficjalnych stron internetowych browarów

Uwzględniając kryterium historyczności, analizowane browary można podzielić na trzy grupy: 1) najstarszy (Lwówek Śląski), 2) XIX-wieczne (Czarnków, Fortuna, Witnica), 3) współczesne (Bartek, Edi, Zodiak).

Ad 2. Dziedzictwo materialne to kryterium, które jest istotne z punktu widzenia przystosowania browaru do potrzeb ruchu turystycznego (rys. 2). Największy potencjał ma Browar Lwówek Śląski, gdyż w 2010 r. uruchomiono w jego wnętrzach Muzeum Dolnośląskiego Browarnictwa. Jest ono 


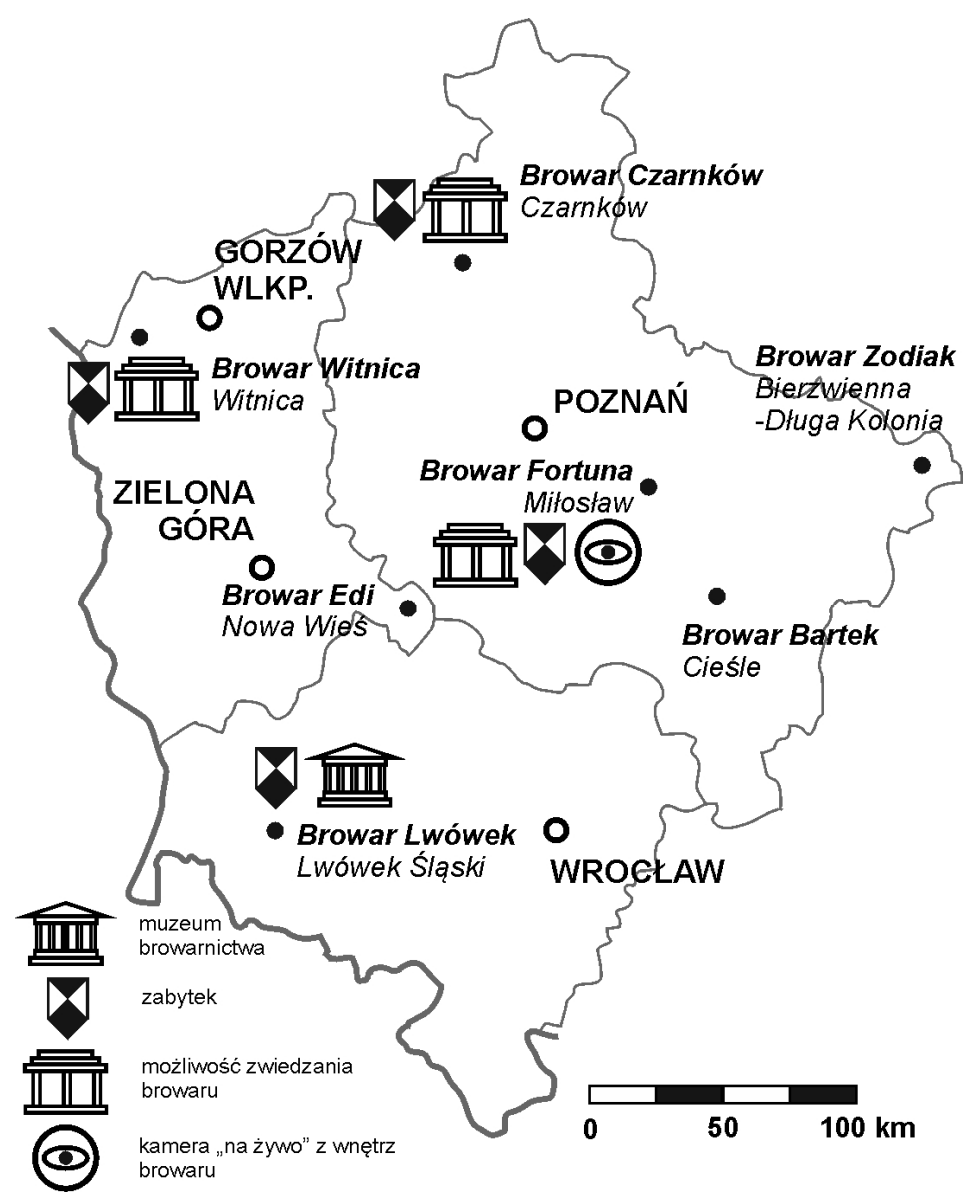

Rys. 2. Przystosowanie do potrzeb turystyki browarów regionalnych Wielkopolski, Dolnego Śląska i Ziemi Lubuskiej

Źródło: opracowanie własne na podstawie danych z oficjalnych stron internetowych browarów

jedynym tego typu obiektem na Dolnym Śląsku i jednym z kilku w Polsce, gdzie zgromadzono blisko 400 eksponatów dokumentujących historię lwóweckiego browarnictwa. W specjalnie przygotowanych gablotach znajdują się niepowtarzalne kolekcje butelek i zamknięć z blisko 40 browarów, które działały dawniej na Dolnym Śląsku. Zgromadzono tu także dawne urządzenia służące do wytwarzania piwa i jego przechowywania (m.in. oryginalna lodówka służąca do schładzania piwa z 1905 r. oraz beczka ze stali nierdzewnej z 1935 r.). Dodatkowo znajduje się tu unikatowa kolekcja kufli, 
etykiet, szyldów i skrzynek. Nieodłączną częścią zwiedzania muzeum jest poznanie z muzealnym przewodnikiem procesu produkcyjnego lwóweckiego piwa, poprzez projekcję filmu i wizytę $w$ warzelni, leżakowni i rozlewni. Obiekt znajduje się w rejestrze zabytków i wyglądem nawiązuje do XIX-wiecznego obiektu, mimo że podczas ostatniego remontu rozebrany został zabytkowy komin kotłowni, nadający charakter całemu kompleksowi (http:// browar-lwowek.com.pl/index.php/browar/muzeum-browarnictwa). Kolejne trzy obiekty - Witnica, Fortuna i Czarnków - oferują zwiedzanie wnętrz. Browar Witnica można poznać podczas 45-minutowej wycieczki, w grupach minimum 15-osobowych pod opieką przewodnika, w ramach której zaplanowana jest degustacja piwa (http://www.strefabiznesu.gazetalubuska. pl/strona/boss-browar-witnica-lubuski-lider-biznesu-2012). Browary Fortuna i Czarnków oferują okazjonalne zwiedzanie podczas imprez regionalnych i wycieczek specjalistycznych, jakimi są wizyty piwowarów i birofilii. Dodatkową atrakcją jest obraz „na żywo” z fermentowni browaru Fortuna, ukazujący proces otwartej fermentacji. Wszystkie budynki wymienionych browarów znajdują się w rejestrze zabytków. Pozostałe browary - Bartek, Edi, Zodiak - nie oferują zwiedzania, a zabudowa obiektów jest w całości współczesna.

Uwzględniając kryterium dziedzictwa materialnego analizowane browary można podzielić na przystosowane i nieprzystosowane do obsługi turystów, czyli: 1) browar z placówką muzealną (Lwówek Śląski), 2) browary z możliwością zwiedzania wnętrz (Czarnków, Fortuna i Witnica), 3) browary bez oferty turystycznej (Bartek, Edi, Zodiak).

Ad 3. Dziedzictwo niematerialne to kryterium, które uwzględnia uczestnictwo browaru w festiwalach tradycji kulinarnej, piwowarskiej i imprezach regionalnych, współtworząc niematerialne dziedzictwo własne i regionu oraz obejmując zgodnie z konwencją w sprawie ochrony dziedzictwa niematerialnego tradycję, przekazy ustne, zwyczaje oraz wiedzę i praktyki dotyczące przyrody (rys. 3) (http://www.nid.pl/idm,1271,niematerialne-dziedzictwo-kulturowe-unesco.html).

Najaktywniejsze pod tym względem są browary Witnica i Lwówek Śląski. Pierwszy z nich uczestniczy w Chmielakach Krasnostawskich (najważniejszy festiwal piwny w kraju), jak również w imprezach regionalnych: Lubuskie Święto Chleba w Bogdańcu, Targi Rolnicze w Lubniewicach, Dzień Świętego Patryka oraz 750-lecie Witnicy, na które wyprodukował limitowaną serię piwa w 2-litrowej butelce. Drugi uczestniczy w festiwalach i im- 
prezach nawiązujących do tradycji regionalnych: Festiwal Dobrego Piwa we Wrocławiu, Lwówecki Festiwal Smaków i Tradycji Regionalnych (http:// www.potrawyregionalne.pl/153,4374,LWOWECKIE_SMAKI_I_TRADYCJE), Lwówecka Biesiada Browarów Regionalnych oraz Lwóweckie Lato Agatowe. Kolejnym jest browar Fortuna uczestniczący w Chmielakach Krasnostawskich, podobnie jak browary Bartek, Czarnków i Edi, a także we Wrocławskim Festiwalu Piwa. Brak jakiejkolwiek wzmianki o uczestnictwie w tego typu festiwalach i imprezach Browaru Zodiak z Kłodawy.

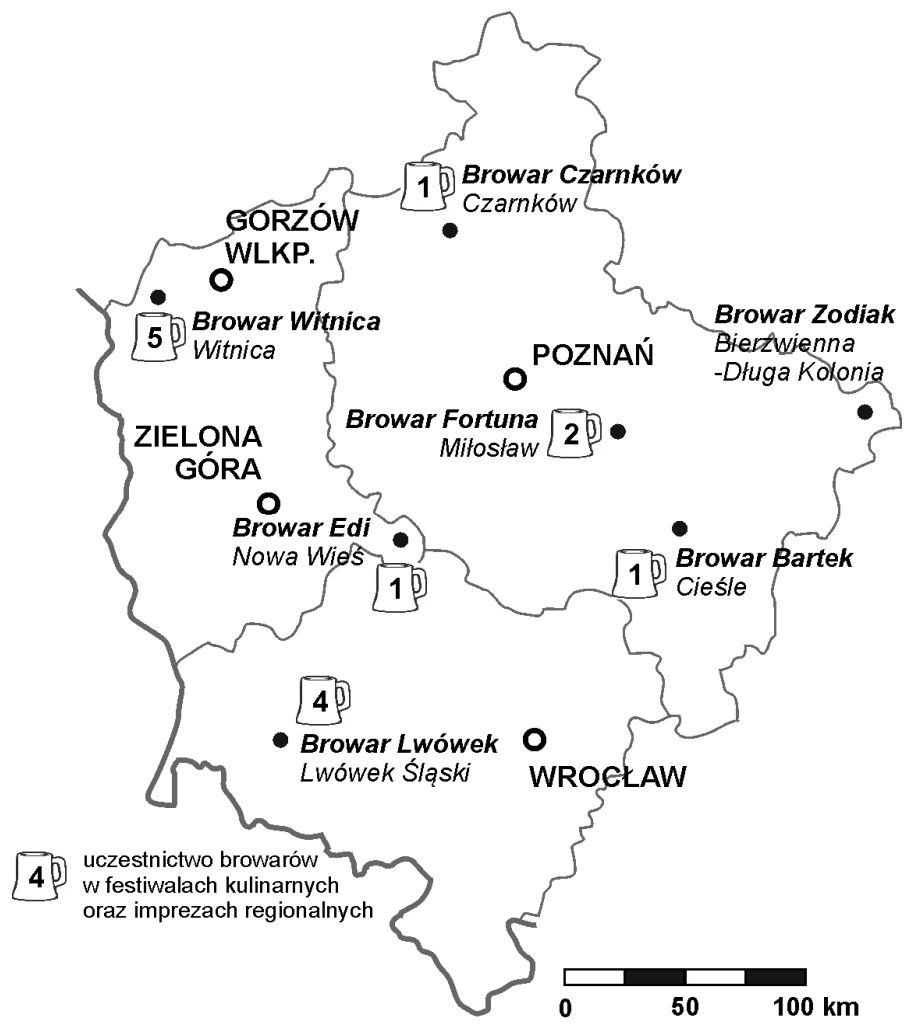

Rys. 3. Uczestnictwo browarów regionalnych Wielkopolski, Dolnego Śląska i Ziemi Lubuskiej w festiwalach kulinarnych i imprezach regionalnych Źródło: opracowanie własne na podstawie danych z oficjalnych stron internetowych browarów

Uwzględniając trzecie kryterium, analizowane obiekty można podzielić na trzy grupy (bez Browaru Zodiak): 1) bardzo aktywne (Witnica, Lwówek Śląski), 2) aktywne (Fortuna), 3) mało aktywne: Bartek, Czarnków i Edi. 


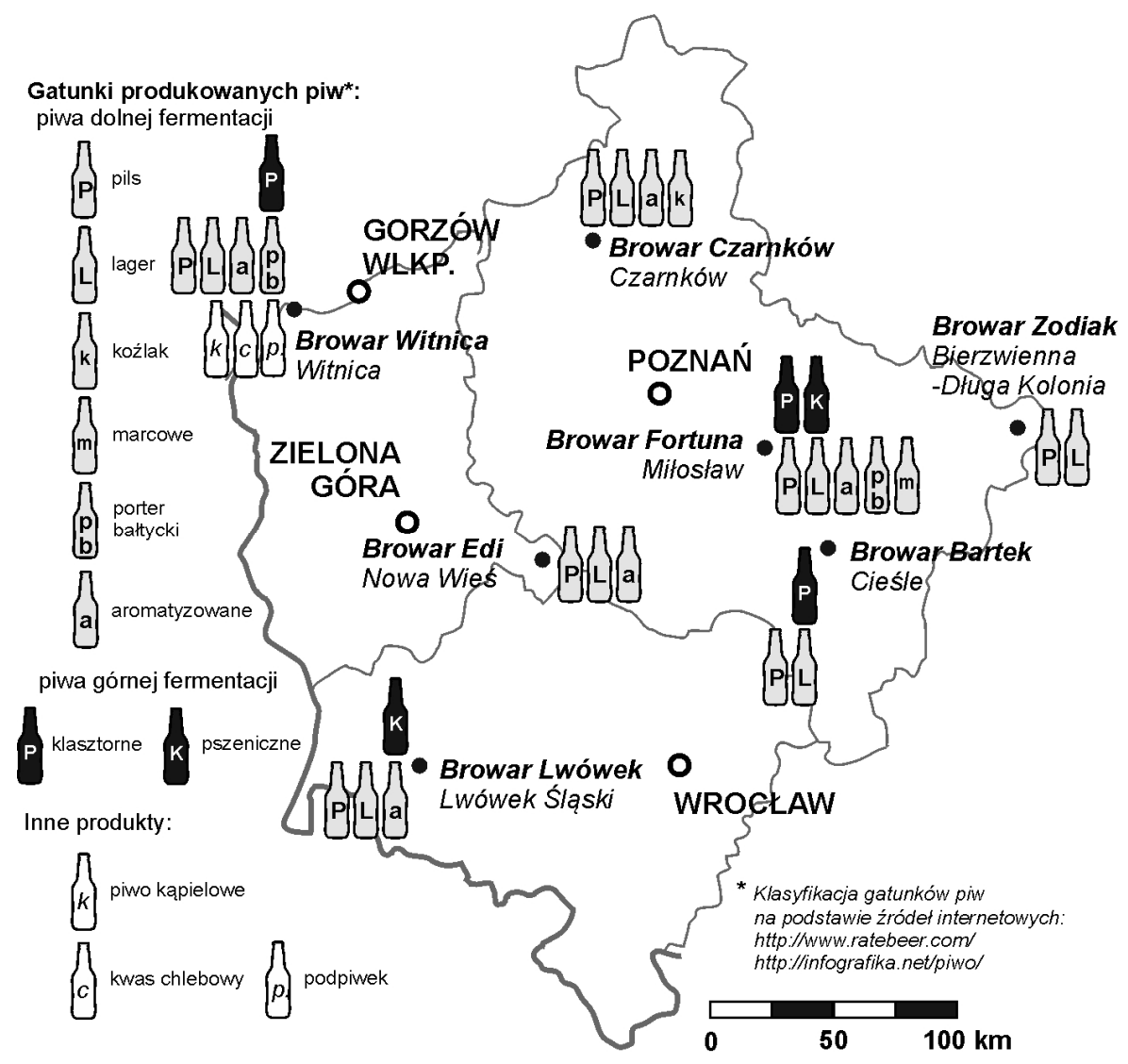

Rys. 4. Różnorodność gatunków piw produkowanych w browarach regionalnych Wielkopolski, Dolnego Śląska i Ziemi Lubuskiej

Źródło: opracowanie własne na podstawie danych z oficjalnych stron internetowych browarów

Ad 4. Różnorodność gatunków piw w danym browarze odzwierciedla wiedzę, umiejętności i doświadczenie jego technologów oraz możliwości finansowo-organizacyjne właścicieli. Najistotniejsze jest stworzenie takich gatunków, które na tle innych produktów wyróżniają dany browar odpowiednią kompozycją słodu i drożdży oraz technologią jego wytwarzania. Najbogatszą ofertę, w tym piwa dolnej i górnej fermentacji, mają browary Fortuna, Witnica i Lwówek Śląski. Nie licząc najpopularniejszych typów, takich jak: lager, pils i ich aromatyzowane odmiany, pierwszy oferuje piwo marcowe, porter bałtycki oraz pszeniczne i klasztorne (ale dubbel i tripel) (http://wrzesnia.info.pl/g/miłosław/item/1649), drugi - porter bałtycki i psze- 
niczne, a trzeci - klasztorne. Węższa oferta charakteryzuje browary Czarnków i Edi produkujące piwa dolnej fermentacji - lager, pils, aromatyzowane - a w przypadku pierwszego z nich, koźlaka. Do grupy tej należy także zaliczyć browar Bartek oferujący wyłącznie piwa lager i pils oraz pszeniczne. $\mathrm{W}$ tym zestawieniu najwęższą ofertę ma browar Zodiak - jedynie piwa typu lager i pils.

W przypadku różnorodności produkowanych gatunków piw analizowane obiekty należy podzielić na trzy grupy: 1) z najszerszą ofertą (Fortuna, Witnica i Lwówek Śląski), 2) z węższą ofertą (Czarnków i Edi, Bartek), 3) ze skromną ofertą (Zodiak).

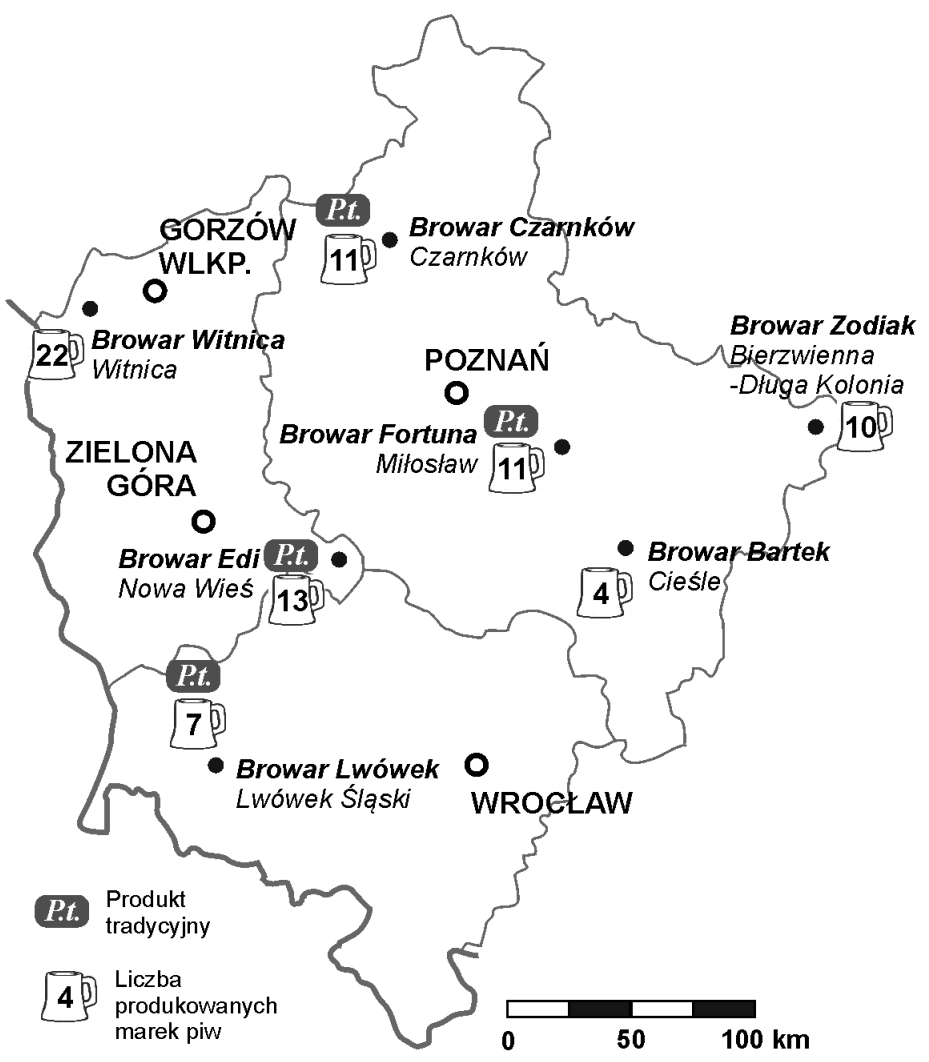

Rys. 5. Oferta produktowa browarów regionalnych Wielkopolski,

Dolnego Śląska i Ziemi Lubuskiej

Źródło: opracowanie własne na podstawie danych z oficjalnych

stron internetowych browarów 
Ad 5. Liczba marek piw to kryterium niezależne od produkowanych gatunków, bowiem poszczególne browary oferują odmienną liczbę marek piwa (rys. 5). W tym względzie bezkonkurencyjny jest browar Witnica produkujący 22 marki piwa, w tym piwo kąpielowe i aromatyzowane jabłkowe, jagodowe, cytrynowe, czekoladowe i cappuccino oraz napoje zaliczane do bezalkoholowych, jak podpiwek i kwas chlebowy. Skromniejszą ofertę mają kolejne cztery browary, których niebywałym atutem jest wyróżnienie produkowanego piwa jako produktu tradycyjnego. Browar Edi oferuje 13 marek piwa, w tym aromatyzowane - migdałowe, miętowe, imbirowe, malinowe i anyżowe, oraz Wschowskie, będące produktem tradycyjnym. Browary Fortuna i Czarnków posiadają 11 marek piwa, w tym produkty tradycyjne, takie jak Czarna Fortuna i Noteckie. Browar Lwówek Śląski oferuje siedem marek piw, w tym Lwóweckie Książęce jako produkt tradycyjny. Kolejny w zestawieniu jest browar Zodiak produkujący 10 marek piwa, a najuboższą ofertę czterech marek piwa ma browar Bartek.

Uwzględniając ofertę produktową analizowane obiekty należy podzielić na trzy grupy: 1) Witnica z największą ofertą oraz Edi, Fortuna, Czarnków i Lwówek Śląski z produktami tradycyjnymi, 2) Zodiak, 3) Bartek z najskromniejszą ofertą.

Ad 6. Dostępność piw to kryterium w przypadku którego przyjęto, że czynnikiem bardziej sprzyjającym rozwojowi turystyki jest dostępność produktu wyłącznie na rynku regionalnym (województwa macierzyste i ościenne), co motywuje do przybycia do danego regionu. Ponadto produkty mogą być dostępne na rynku ponadregionalnym (inne województwa niż powyższe) oraz w całym kraju. W tym względzie analizowane browary można podzielić jedynie na dwie grupy pod względem dostępności, gdyż żadne z piw nie jest dostępne w całej Polsce: 1) rynek regionalny (Bartek, Edi, Lwówek Śląski i Zodiak), 2) rynek ponadregionalny (Czarnków, Fortuna, Witnica).

\section{Wnioski}

Przedstawiona charakterystyka i ocena siedmiu obecnie działających browarów regionalnych na terenie Wielkopolski, Dolnego Śląska i Ziemi Lubuskiej ukazuje duże zróżnicowane możliwości rozwoju turystyki piwnej. Wyniki 
przedstawia rys. 6, na potrzeby którego ustalono punktację od 0 do 3 ( 0 - nie spełnia kryterium, 3 - maksymalnie spełnia), pozwalającą lepiej uchwycić zróżnicowanie potencjału poszczególnych browarów.

\begin{tabular}{|l|c|c|c|c|c|c|c|}
\hline \multicolumn{1}{|c|}{$\begin{array}{c}\text { Browar, } \\
\text { miasto }\end{array}$} & I & II & III & IV & V & VI & $\begin{array}{c}\text { Potencjał } \\
\text { turystyczny }\end{array}$ \\
\hline Bartek - Cieśle & 0 & 0 & 1 & 2 & 1 & 3 & mały \\
\hline $\begin{array}{l}\text { Czarnków } \\
- \text { Czarnków }\end{array}$ & 2 & 2 & 1 & 2 & $2+1^{*}$ & 2 & średni \\
\hline $\begin{array}{l}\text { Edi- Nowa Wieś, } \\
\text { Wschowa }\end{array}$ & 0 & 0 & 1 & 2 & $2+1^{*}$ & 3 & mały \\
\hline $\begin{array}{l}\text { Fortuna - Miło- } \\
\text { sław }\end{array}$ & 2 & 2 & 2 & 3 & $2+1^{*}$ & 2 & duży \\
\hline $\begin{array}{l}\text { Lwówek Śláski } \\
\text { 1209- Lwówek } \\
\text { Śląski }\end{array}$ & 3 & 3 & 3 & 3 & $2+1^{*}$ & 3 & największy \\
\hline Witnica - Witnica & 2 & 2 & 3 & 3 & 3 & 2 & duży \\
\hline $\begin{array}{l}\text { Zodiak - Bierz- } \\
\text { wienna }\end{array}$ & 0 & 0 & 0 & 1 & 2 & 3 & mały \\
\hline
\end{tabular}

* Dodatkowa punktacja za produkt tradycyjny z listy Ministerstwa Rolnictwa i Rozwoju Wsi w ofercie browaru.

Rys. 6. Potencjał turystyczny browarów regionalnych Wielkopolski, Dolnego Śląska i Ziemi Lubuskiej Źródło: opracowanie własne

Największym potencjałem dla rozwoju turystyki piwnej w oparciu o zaprezentowane na rys. 6 zestawienie charakteryzuje się Browar Lwówek Śląski, gdyż wyróżnia się najdłuższą tradycją placówką muzealną różnorodną ofertą gatunków piw górnej i dolnej fermentacji, a także promuje się na wielu imprezach. Zbliżoną punktację uzyskały browary z Witnicy i Miłosławia. Jednak powodem wysokiej oceny Witnicy jest głównie ponaddwukrotnie szersza oferta marek w stosunku do reszty browarów. Słabiej pod tym względem prezentują się browary Czarnków i Edi, a najsłabiej Bartek i Zodiak (rys. 7). Wynika to z tego, że nie mają długiej tradycji, ale też ich oferta na tle konkurencji wypada znacznie gorzej; promocja piwa na rynku jest co najmniej niewystarczająca.

Podsumowując należy stwierdzić, że zastosowana metoda jest pierwszą tego typu próbą i z tego względu konieczne są dalsze prace nad jej udoskonaleniem. Obecnie pozwala ona na pewne uogólnienia w przypadku scharakteryzowania potencjału turystycznego. Jej minusem jest jednak nieuwzględnienie jakości i smaku piwa w ocenie konsumentów. Wydaje się, że w przyszłości warto uzupełnić ją o kryterium oceny konsumenckiej. 


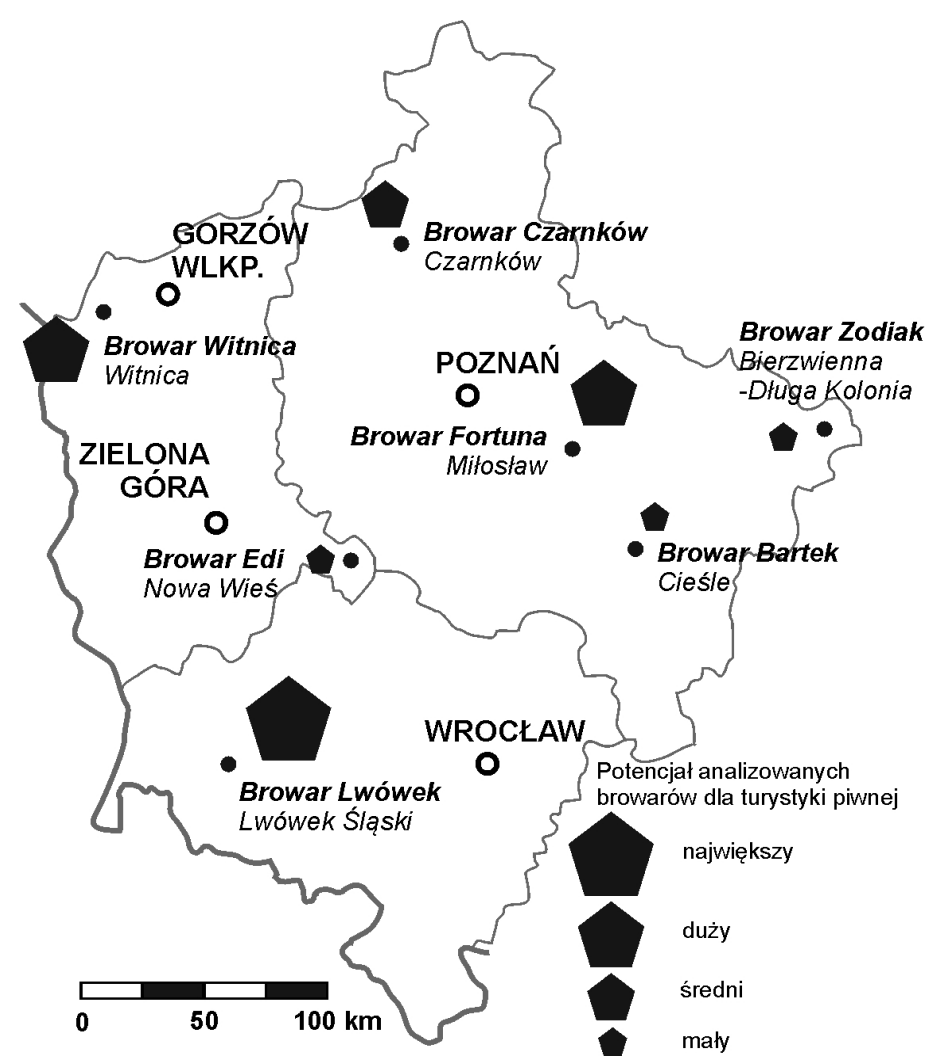

Rys. 7. Potencjał turystyczny browarów regionalnych Wielkopolski,

Dolnego Śląska i Ziemi Lubuskiej

Źródło: opracowanie własne na podstawie danych z oficjalnych stron internetowych browarów

Mając na uwadze odmienny charakter każdego browaru, przy uwzględnieniu jego potencjału dla rozwoju turystyki piwnej, można zaproponować kierunki rozwoju związane $\mathrm{z}$ obsługą ruchu turystycznego. W przypadku Lwówka Śląskiego może to być zwiedzanie połączone z warsztatami warzenia piwa w okresie średniowiecza oraz historią jego produkcji na terenie Europy Środkowej. Witnica, która niegdyś należała do zakonu Cystersów, może zaproponować spotkania mające na celu przybliżenie produkcji piwa klasztornego, natomiast Miłosław i Czarnków powinny budować swoją ofertę uwzględniając przede wszystkim piwa uznane za produkty tradycyjne, organizując różnego rodzaju spotkania i festiwale Piwa Czarnego i Noteckiego. 


\section{BIBLIOGRAFIA}

BiKont P., MakŁowicz R., 2003, Prosto z pipy. Piwny przewodnik 500 pubów w całej Polsce, Wyd. Pascal, Bielsko-Biała.

Fąat Z., Górska R., Plinta P., SAdownik A., Wojtala D., 2002, Przewodnik piwosza, Wyd. Pascal, Bielsko-Biała.

GALAS A., GALAS A., 2004, Dzieje Ślaska w datach, Wyd. „Cadus” Wrocław

JACKSON M., 2007, Tyskie vademecum piwa, Warszawskie Wyd. Literackie Muza, Warszawa.

KosMACZEWSKA J., 2008, Turystyka piwna jako nowy przejaw aktywności turystycznej w Polsce, [w:] W. Siwiński, R. Tauber, E. Mucha-Szajek (red.), Wspótczesne tendencje w rekreacji i turystyce, WSHiG, Wyd. Naukowe Bogucki, Poznań.

KRAUSOVA-ŻUR I., 2010, Czechy. Gospoda petna humoru, Przewodnik turystyczny, Wyd. Bezdroża, Kraków.

Отто P., 2012, Podróż za jeden kufel, czyli turystyka śladami piwa, http://serwisy.gazetaprawna.pl/ turystyka/artykuly/627284,podroz_za_jeden_kufel_czyli_turystury_sladami_piwa.html; 22.10.2012 r.

RogowsKi M., KUC M., KUC M., 2012, Możliwości rozwoju turystyki piwnej w oparciu o małe browary w Polsce, [w:] W. Siwiński, R. Tauber, E. Mucha-Szajek (red.), Społeczno-kulturowe studia z turystyki, rekreacji, hotelarstwa i żywienia, Wyd. Wyższej Szkoły Hotelarstwa i Gastronomii, Poznań.

Strojny A., 2003, Piwnym szlakiem po Europie Środka. Przewodnik turystyczny, Bezdroża, Kraków.

Strojny A., 2009, Browary w Polsce, Wyd. Hachette Livre, Warszawa.

Społeczny kontekst picia piwa - projekt zrealizowany na zlecenie Zwiazku Pracodawców Przemystu Piwowarskiego przez SMG/KRC i Ośrodek Realizacji Badań Socjologicznych IFIS PAN, Warszawa 2003.

http://browarczarnkow.pl/, 18.12.2012 r.

http://browarfortuna.pl/; 18.12.2012 r.

http://pl.wikipedia.org/wiki/Browar_Bartek; 18.12.2012 r.

http://www.browaredi.pl/; 18.12.2012 r.

http://www.browar-lwowek.com.pl/; 18.12.2012 r.

http://www.browar-witnica.pl/; 18.12.2012 r.

http://browar-lwowek.com.pl/index.php/browar/muzeum-browarnictwa; 28.12.2012 r.

http://urlopw.pl/turystyka-piwna-nowy-trend-turystyczny/; 18.12.2012 r.

http://www.nid.pl/idm,1271,niematerialne-dziedzictwo-kulturowe-unesco.html; 28.12.2012 r.

http://www.potrawyregionalne.pl/153,4374,LWOWECKIE_SMAKI_I_TRADYCJE_.htm; 28.12.

$2012 \mathrm{r}$.

http://www.strefabiznesu.gazetalubuska.pl/strona/boss-browar-witnica-lubuski-lider-biznesu2012; 28.12.2012 r

http://zabytki.powiatlwowecki.info/index.php/ciekawe-historie/26-zabytki/niezwykle-historie/

50-historia-lwoweckiego-piwowarstwa; 18.12.2012 r.

http://www.ratebeer.com/ dostęp 28.12.2012 r.

http://pgo24.pl/2012/08/fortuna-nabywca-browaru-w-grodzisku-wielkopolskim/; 28.12.2012 r.

http://wrzesnia.info.pl/g/miłosław/item/1649; 28.12.2012 r.

http://www.smaki-piwa.pl; 28.12.2012 r.

http://sklep.browar-witnica.pl/strony/historia; 28.12.2012 r.

http://www.browarfortuna.pl/historia_browaru/; 28.12.2012 r.

http://browarczarnkow.pl/o-browarze/; 28.12.2012 r. 